\title{
MOLLUSCICIDAL AND MOSQUITOCIDAL ACTIVITIES OF THE ESSENTIAL OILS OF Thymus capitatus HOFF. ET LINK. AND Marrubium vulgare L.
}

Maha M. SALAMA(1), Eman E. TAHER(2) \& Mohamed M. EL-BAHY(3)

\begin{abstract}
SUMMARY
Steam distillation of essential oils of aerial parts of Thymus capitatus and Marrubium vulgare L. collected at North cost of Egypt yielded $0.5 \%$ and $0.2 \%$, respectively. Results of Gas chromatography-mass spectrometry analyses of the two samples identified $96.27 \%$ and $90.19 \%$ of the total oil composition for T. capitatus and M. vulgare, respectively. The two oil samples appeared dominated by the oxygenated constituents ( $88.22 \%$ for T. capitatus and $57.50 \%$ for $M$. vulgare), composed of phenols, mainly carvacrol (32.98\%) and thymol (32.82\%) in essential oil of T. capitatus, and thymol (34.55\%) in essential oil of M. vulgare. It was evaluated the molluscicidal activity of T. capitatus and M. vulgare essential oils on adult and eggs of Biomphalaria alexandrina as well as their mosquitocidal activity on Culex pipiens. The $\mathrm{LC}_{50}$ and $\mathrm{LC}_{90}$ of T. capitatus essential oil against adult snails was 200 and $400 \mathrm{ppm} / 3 \mathrm{hrs}$, respectively, while for M. vulgare it was 50 and $100 \mathrm{ppm} / 3 \mathrm{hrs}$, respectively. Moreover, $M$. vulgare showed $\mathrm{LC}_{100}$ ovicidal activity at $200 \mathrm{ppm} / 24 \mathrm{hrs}$ while T. capitatus oil showed no ovicidal activity. It was verified mosquitocidal activity, with $\mathrm{LC}_{50}$ and $\mathrm{LC}_{90}$ of 100 and $200 \mathrm{ppm} / 12 \mathrm{hrs}$ respectively for larvae, and 200 and $400 \mathrm{ppm} / 12 \mathrm{hrs}$ respectively for pupae of C. pipiens.
\end{abstract}

KEYWORDS: Vector control; Plant products; Thymus capitatus; Marrubium vulgare.

\section{INTRODUCTION}

Vector borne diseases are major sources of illness and death worldwide. Mosquitoes are primary vectors for many dreadful and fatal diseases such as dengue, malaria, yellow fever and filariasis. It can transmit diseases to more than 700 million people each year ${ }^{8,33}$. Lymphatic filariasis infects 120 million people in 73 countries worldwide and continues to be a worsening problem, especially in Africa and the Indian subcontinen ${ }^{28}$. Control of such diseases is becoming increasingly difficult because of increasing resistance to synthetic insecticides ${ }^{29}$.

Schistosomiasis affects more than 200 million people worldwide and is considered as the world's most widespread parasitic disease ${ }^{19}$. The life cycle of the parasite in Egypt includes Biomphalaria and Bulinus snails as intermediate hosts ${ }^{12}$. Interruption of the parasite's life cycle, via control of the snail's population, is one of the strategies to combat schistosomiasis ${ }^{38}$. Molluscicidal agents thus interrupt the life cycle of the causative parasite and prevent human infection ${ }^{21}$.

Using natural products of plant origin (botanical derivatives) is an alternative and recent approach for mosquito and snail control. Despite their toxicity to pests and snails, they are readily biodegradable and usually lack toxicity to higher animals so they are eco-friendly ${ }^{4,5}$. Essential oils of plants are outstanding candidates, since they are; in some cases; highly active, readily available in tropical countries and economically viable $^{21}$. Essential oils molluscicidal and mosquitocidal activities have been reported by many studies ${ }^{23,24,27}$.

Thymus capitatus Hoff. et Link. and Marrubium vulgare L. are aromatic plants belonging to the family Lamiaceae. They are distributed along the Mediterranean area, at the North coast of Egypt. Few reports dealt with mosquitocidal activity of T. vulgaris ${ }^{7,18}$ and nothing was traced concerning the mosquitocidal activity of $M$. vulgare or the molluscicidal activity of both plants. In this respect, the present work is an attempt to characterize the different constituents of oils hydro distilled from $T$. capitatus and $M$. vulgare and to evaluate the effect of these essential oils of both plants on B. alexandrina snails and their egg masses as well as on larvae and pupae of Culex pipiens.

\section{MATERIAL AND METHODS}

Plant material: The aerial parts of T. capitatus and $M$.vulgare were collected from the North coast of Egypt during April 2010. Authentication of the plant was established in the herbarium of the Department of Pharmacognosy, Faculty of Pharmacy, Cairo University, Egypt. Voucher specimens (No. T-12 and M-22).

Preparation of the essential oil: Fresh aerial parts $(500 \mathrm{~g})$ of both 
plants under investigation were separately subjected to hydrodistillation (HD) in a Clevenger-type apparatus and the oil obtained from each plant was dried over anhydrous sodium sulfate and stored in a refrigerator till analysis. The percentage yield for each sample was determined. The specific gravity and refractive index for each oil sample were also determined $^{13}$.

Analysis of the oils: Investigation of the prepared oils was carried out on an Agilent (USA) Gas Chromatography-Mass Spectrometry system (GC-MS), model 6890, fitted with an Agilent mass spectroscopic detector (MSD), model 5937, as well as a $30 \mathrm{~m}$ long, cross-linked 5\% phenyl polysiloxane (HP-5MS, Hewlett Packard, USA) fused-silica column (i. d. $0.25 \mathrm{~mm}$, film thickness $0.25 \mu \mathrm{m})$. The initial temperature was $80{ }^{\circ} \mathrm{C}$, kept isothermal for three min, then increased to $260^{\circ} \mathrm{C}$ at $8{ }^{\circ} \mathrm{C} / \mathrm{min}$, and the final temperature was kept isothermal for $15 \mathrm{~min}$. The ion source temperature was $230^{\circ} \mathrm{C}$ and the quadrupole temperature was $150{ }^{\circ} \mathrm{C}$. The carrier gas was helium adjusted at a flow rate of $0.1 \mathrm{~mL} / \mathrm{min}$. Ionization energy was $70 \mathrm{eV}$, and scan range was $40-500 \mathrm{~m} / \mathrm{z}$ at 3.62/scan.

Identification of the oil components: Search for identification of the oil components was carried out using the Willey 275 L GC-MS library data base. A series of authentic $n$-alkanes (C8-C22, Poly Science Inc., Niles, USA) was subjected to Gas Liquid Chromatography (GLC) analysis under the same experimental conditions. The retention indices (Kovat's indices, KI) of the volatile constituents were computed by logarithmic interpolation between bracketing alkanes ${ }^{17}$. Identification of the individual components was confirmed by comparison of their retention indices and MS fragmentation patterns with published data ${ }^{2}$. Relative percentages were calculated from the Total Ion Chromatograms by the computerized integrator .Results of GC/MS analysis and for the relative percentages are shown in Tables 1 and 2 respectively.

Table 1

Results of GC/MS analysis of the essential oil of Thymus capitatus Hoff. et Link. and Marrubium vulgare L.

\begin{tabular}{|c|c|c|c|c|c|}
\hline \multirow{2}{*}{ No. } & \multirow{2}{*}{ Rt (min.) } & \multirow{2}{*}{ KI } & \multirow{2}{*}{ Identified compound } & \multicolumn{2}{|c|}{ Percentage } \\
\hline & & & & T. capitatus & M. vulgare \\
\hline 1 & 9.08 & 1167 & Borneol & 9.15 & |-------- \\
\hline 2 & 11.24 & 1293 & Thymol & 32.82 & 34.55 \\
\hline 3 & 11.67 & 1298 & Carvacrol & 32.98 & 4.35 \\
\hline 4 & 12.1 & 1335 & $\delta$-Elemene & --------- & 2.16 \\
\hline 5 & 12.37 & 1347 & $\alpha$-Terpinyl acetate & --------- & 0.51 \\
\hline 6 & 12.41 & 1355 & Thymol acetate & 3.27 & --------- \\
\hline 7 & 12.71 & 1368 & Carvacrol acetate & 1.8 & --------- \\
\hline 8 & 12.98 & 1403 & Caryophyllene & 6.15 & --------- \\
\hline 9 & 13.42 & 1431 & $\gamma$-Elemene & ------- & 1.24 \\
\hline 10 & 13.45 & 1443 & Aromandrene & 0.43 & ------- \\
\hline 11 & 13.72 & 1451 & $\alpha$-Humulene & 0.3 & 1.89 \\
\hline 12 & 13.80 & 1479 & Germacrene D & -------- & 0.74 \\
\hline 13 & 13.90 & 1480 & $\alpha$-Amorphene & ----- & 2.39 \\
\hline 14 & 13.93 & 1509 & $\gamma$-Cadinene & ------ & 17.68 \\
\hline 15 & 13.98 & 1516 & $\delta$-Cadinene & 0.38 & 2.21 \\
\hline 16 & 14.05 & 1525 & $\alpha$-Cadinene & -------- & 2.97 \\
\hline 17 & 14.12 & 1559 & $\alpha$-Muurolene & -------- & 1.20 \\
\hline 18 & 14.45 & 1566 & Germacrene D-4-ol & -------- & 6.37 \\
\hline 19 & 15.90 & 1568 & Spathulenol & 1.2 & --------- \\
\hline 20 & 15.96 & 1580 & Caryophyllene oxide & 3.45 & 1.74 \\
\hline 21 & 16.75 & 1636 & Caryophylla-4(14),8,(15)-diene-5- $\beta$-ol & 1.17 & 2.55 \\
\hline 22 & 17.03 & 1640 & Alloaromadendrene & 1.01 & ------ \\
\hline 23 & 17.32 & 1652 & $\alpha$-Cadinol & --------- & 5.39 \\
\hline 24 & 17.41 & 1671 & $\alpha$-Bisabolol & 0.64 & ------ \\
\hline 25 & 18.12 & 1740 & Cucurmenol & ------- & 0.95 \\
\hline 26 & 18.76 & 1768 & Pentadecanol & 0.2 & 1.09 \\
\hline 27 & 20.33 & 1881 & $n$-Hexadecanol & 0.53 & ------- \\
\hline 28 & 22.25 & 2015 & $n$-Heneicosane & 0.48 & ------- \\
\hline 29 & 24.39 & 2292 & $n$-Tricosane & 0.31 & 0.21 \\
\hline
\end{tabular}

Rt, retention time; KI, Kovat's index. 


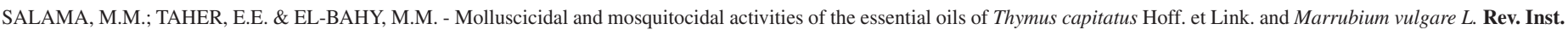
Med. Trop. Sao Paulo, 54(5): 281-6, 2012.

Table 2

Percentages of the different classes of constituents identified by GC/MS in the essential oils of Thymus capitatus Hoff. et Link. and Marrubium vulgare L.

\begin{tabular}{lcc}
\hline \multirow{2}{*}{ Class } & \multicolumn{2}{c}{ Percentage } \\
\cline { 2 - 3 } & T. capitatus & M. vulgare \\
\hline Hydrocarbons & $\mathbf{8 . 0 5}$ & $\mathbf{3 2 . 6 9}$ \\
• Sesquiterpenes & 7.26 & 32.48 \\
• Non-terpenoid hydrocarbons & 0.79 & 0.21 \\
Oxygenated constituents & $\mathbf{8 8 . 2 2}$ & $\mathbf{5 7 . 5}$ \\
• Monoterpenes & 9.15 & 0.51 \\
• Sesquiterpenes & 7.67 & 18.09 \\
• Other oxygenated constituents & 71.4 & 38.9 \\
\hline
\end{tabular}

Collection and laboratory maintenance of snails: Biomphalaria alexandrina snails and egg masses were collected and identified from irrigation canals in Giza Governorate ${ }^{9}$. Snails were screened for natural infection with larval trematodes. Uninfected snails were maintained in the laboratory conditions for seven days before being used in the study in dechlorinated tap water and fed daily on green lettuce. Tests were carried out at room temperature $\left(26+1^{\circ} \mathrm{C}\right)$. In each step, a fine mesh was placed over the container to prevent snails crawling out of the container.

Molluscicidal bioassay: The bioassay of molluscicidal activity against the $B$. alexandrina was evaluated according to the established procedure $^{36}$. Five adult snails $(8-14 \mathrm{~mm}$ in diameter) and snail's egg masses (three days old) were placed, separately, in a beaker containing $200 \mathrm{~mL}$ of essential oil water solution of T. capitatus and M. vulgare at a series of concentrations ranging from 75-1000 parts per million (ppm) for each tested plant oil. Each experiment was set in triplicate. Snails and egg masses remained in dechlorinated water during the experiment served as control group. Immersion technique was adopted according to $\mathrm{WHO}^{35}$. Adult snails and egg masses were exposed for $24 \mathrm{~h}$ at room temperature. After $24 \mathrm{~h}$, snails were rinsed twice with aerated tap water. At the end of this period; tested snails and egg masses were examined to assess mortality. Mortality was evaluated using crushing technique $(5 \% \text { sodium hydroxide solution })^{35}$. Egg masses were examined under the microscope for detecting the embryos and its vitality.

Snails were considered dead if they remained motionless, did not respond to the presence of food or if the shell looked discolored. The number of dead snails was expressed as percent mortality. The lethal concentration to $50 \%\left(\mathrm{LC}_{50}\right)$ and $90 \%\left(\mathrm{LC}_{90}\right)$ for snails and $100 \%\left(\mathrm{LC}_{100}\right)$ for the eggs was calculated following the method of Finney ${ }^{15}$. Samples that caused no mortality at $1000 \mathrm{ppm}$ were considered inactive and were not investigated.

Mosquitocidal bioassay: Eggs of $C$. pipiens were obtained from The Medical Research Institute of Insects, Giza, Egypt were soaked in dechlorinated tap water to develop into first instar larvae. Larvae were reared in the same aquarium until the development of third instar larvae and pupae. Twenty $C$. pipiens third instar larvae as well as pupae were picked up from the aquarium and located in a $200 \mathrm{~mL}$ beaker. The bioassay was done according to WHO guidelines with slight modifications ${ }^{37}$. Essential oils of both $T$. capitatus and $M$. vulgare were tested at the same concentrations as those applied for snails for each tested plant. Stock solution of the essential oil was prepared in Tween 80. From this stock solution, concentrations of 12.5, 25, 50, 100 and 200 ppm were prepared and replicated three times for each concentration. Mosquitoes were exposed to essential oils for $24 \mathrm{~h}$ at room temperature, and were kept under normal laboratory conditions at $26 \pm 2{ }^{\circ} \mathrm{C}$ and 60 $\pm 10 \%$ relative humidity with $12: 12 \mathrm{D} / \mathrm{L}$ photoperiod. Mortality was recorded after 24 hours of continuous exposure during which no food was offered to the test organisms. The $\mathrm{LC}_{50}$ and $\mathrm{LC}_{90}$ of tested plants, 95\% confidence interval and their slopes of probit regression line were determined to probit analysis program to compare their effectiveness ${ }^{30}$.

\section{RESULTS}

Steam distillation of the essential oils of T. capitatus and M. vulgare yielded $0.5 \%$ and $0.2 \%$, respectively. The specific gravity and refractive index (at $25{ }^{\circ} \mathrm{C}$ ) for $T$. capitatus were 0.8561 and 1.5213 , respectively while those of $M$. vulgare were 0.9562 and 1.6705 , respectively. Results of GC/MS analyses of the two samples are displayed in Table 1. Numbers of the identified components in both oils were 18 and 19, amounting to $96.27 \%$ and $90.19 \%$ of the total oil composition for T. capitatus and $M$. vulgare respectively. Constituents identified under the adopted operating conditions of the essential oils under investigation were 29. Detected components in both samples viz., thymol, carvacrol, $\delta$-cadinene, caryophyllene oxide, caryophylla-4(14), 8,(15)-diene-5- $\beta$-ol, $n$-tricosane, pentadecanol and humulene. The rest of constituents appeared, however, unevenly distributed in the analyzed oils.

The identified amount of oxygenated constituents were $88.22 \%$ and $57.50 \%$ for $T$. capitatus and M. vulgare, respectively (Table 2) while the amount of identified hydrocarbons was $8.05 \%$ and $32.69 \%$, respectively. The overall chromatographic profile of the two oil samples was dominated by the oxygenated constituents. These were mainly composed of phenols among which carvacrol (32.98\%) and thymol (32.82\%) were the major constituents in T. capitatus oil while in M. vulgare oil thymol (34.55\%) was the major constituent. Borneol, bicyclic monoterpenoid alcohol, was only present in T. capitatus oil (9.15\%). Sesquiterpenes were the major class of hydrocarbons in the two oil samples amounted to $7.26 \%$ and $32.48 \%$ while non-terpenoid hydrocarbons were only $0.79 \%$ and $0.21 \%$ for $T$. capitatus and M. vulgare oils, respectively. The major sesquiterpene hydrocarbon in T. capitatus was z-caryophyllene $(6.15 \%)$ while $\gamma$-cadinene was the major sesquiterpene hydrocarbon in $M$. vulgare oil $(17.68 \%)$.

Molluscicidal activity of $T$. capitatus and M. vulgare essential oils against adult $B$. alexandrina and egg masses was evaluated at different concentrations ranging from 75-1000 ppm. After screening; the $\mathrm{LC}_{50}$ and $\mathrm{LC}_{90}$ of T. capitatus essential oil versus adult snails were 200 and 400 $\mathrm{ppm} / 3 \mathrm{hrs}$, respectively while of $M$. vulgare essential oil were 50 and 100 ppm/3hrs, respectively (Table 3). Furthermore, M. vulgare oil showed $100 \%$ snail ovicidal activity against $B$. alexandrina eggs at 200 ppm/24 hrs. However, T. capitatus oil showed no snail ovicidal activity (Table 3 ).

Concerning mosquitocidal activity, both $T$. capitatus and $M$. vulgare oils gave 50\% and $90 \%$ larvicidal activity at 100 and 200 ppm/12hrs, respectively. Moreover, both samples showed $50 \%$ and $90 \%$ pupicidal activity at 200 and 400 ppm/12hrs, respectively (Table 4). 


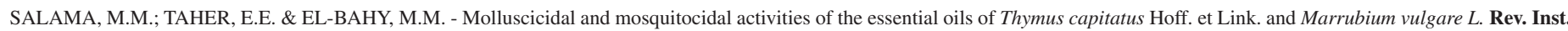
Med. Trop. Sao Paulo, 54(5): 281-6, 2012.

Table 3

Results of molluscicidal activity of essential oils of Thymus capitatus Hoff. et Link. and Marrubium vulgare L. against Biomphalaria alexandrina after $3 \mathrm{hr}$ exposure period

\begin{tabular}{lccc}
\hline \multirow{2}{*}{ Essential oil } & \multicolumn{2}{c}{ Adult snails } & Eggs \\
\cline { 2 - 4 } & $\mathrm{LC}_{50}$ & $\mathrm{LC}_{90}$ & LC $_{100}$ \\
\hline T. capitatus & $200 \mathrm{ppm}$ & $400 \mathrm{ppm}$ & No effect \\
$M$. vulgare & $50 \mathrm{ppm}$ & $100 \mathrm{ppm}$ & $200 \mathrm{ppm} *$ \\
\hline
\end{tabular}

* After $24 \mathrm{hr}$

Table 4

Results of larvicidal activity of the essential oils of Thymus capitatus

Hoff. et Link. and Marrubium vulgare L. against Culex pipiens after $12 \mathrm{~h}$ exposure period

\begin{tabular}{lcccc}
\hline \multirow{2}{*}{ Essential oil } & \multicolumn{2}{c}{ Larvae } & \multicolumn{2}{c}{ Pupae } \\
\cline { 2 - 5 } & $\mathrm{LC}_{50}$ & $\mathrm{LC}_{90}$ & $\mathrm{LC}_{50}$ & $\mathrm{LC}_{90}$ \\
\hline T. capitatus & $100 \mathrm{ppm}$ & $200 \mathrm{ppm}$ & $100 \mathrm{ppm}$ & $200 \mathrm{ppm}$ \\
M. vulgare & $200 \mathrm{ppm}$ & $400 \mathrm{ppm}$ & $200 \mathrm{ppm}$ & $400 \mathrm{ppm}$ \\
\hline
\end{tabular}

\section{DISCUSSION}

Among the most promising advances in the field of drug development is discovering new molecules or novel uses of the already available compounds with known safety and without any side effects. Thymol is a naturally occurring phenolic monoterpene, known for its antioxidant, anti-inflammatory, antimicrobial, antileishmanial, antimalarial, antiprotozoal, insecticidal and molluscicidal activities ${ }^{6,14}$. Phenolic compounds were proved to be useful in a variety of molluscicidal applications ${ }^{21}$. Thymol showed also considerable molluscicidal effect against B. alexandrina, Bulinus truncatus and Lymnaea natalensis ${ }^{14}$. An isomer of thymol, namely carvacrol, showed in vitro antifilarial activity but to a lesser extent than thymol ${ }^{25}$. Furthermore, some studies revealed that carvacrol has an antibacterial, antifungal, antiparasitic and antioxidants activities ${ }^{31}$. According to these results, two members of the Lamiaceae cultivated in Egypt ( $T$. capitatus and M. vulgare) were screened for the presence of thymol in their essential oils. Both oils contain thymol in high content so they are screened for their molluscicidal and insecticidal activities as a way to relate these activities with the previous findings of thymol itself.

Both oils showed promising molluscicidal activity against $B$. alexandrina snails and mosquitocidal activity versus $C$. pipiens larvae and pupae. These activities may be attributed to thymol or its isomer carvacrol which agreed with other studies ${ }^{32}$. Volatile oils caused significant behavioral changes in snails with the most obvious sign of distress being muscular and spiral twisting of the body followed by crawling on one another. The nature and rapid onset of these responses showed that these oils probably contain neurotoxins that might be active at the neuromuscular system of exposed animals ${ }^{39}$. Similar metabolic disorders on life were revealed including egg laying, egg hatchability, hepatic cells damages, lack of smooth transmission at nerve junction, loss of muscular coordination and convulsions, then snails' death ${ }^{1}$.
The results of the present study might be attributable also to the high sesquiterpene content of Marrubuim (50.57\%) as compared to oil of Thymus (14.93\%). Sesquiterpenoids are credited with various biological actions. They may kill snails as well as snail egg masses via contact poisoning resulting in killing the early egg embryos ${ }^{11}$. These findings are in accordance with other studies that mentioned sesquiterpenes as promising skin penetration enhancers with specific P-glycoprotein modulators that can reverse cellular multidrug resistance by inhibiting the drug efflux process ${ }^{26,34}$. Other studies also stated that antimicrobial properties of essential oils from $M$. vulgare are associated with their high contents of oxygenated compounds $(46.21 \%)^{41}$. Researchers also reported mono and sesquiterpenoids as the major components of essential oils which are phenolic in nature ${ }^{40}$. It is therefore reasonable to assume that their antimicrobial activity might be related to the abundance of phenolic compounds ${ }^{21}$.

It was reported that methanolic extracts from many plants had the maximum larvicidal activity against $C$. pipiens larvae; moreover, plant extracts have been shown to have good effective control properties on mosquitoes besides being environmental friendly bio-pesticide ${ }^{20}$. On the contrary, other studies revealed that methanolic extracts were less effective than the extracts of other essential oils ${ }^{3}$. Researchers suggested that larvicides affect mosquito in one of three possible mechanisms; by physical flooding of the tracheal system or by toxicity specially that of volatile components and by interference with surface forces ${ }^{10}$. Different sensitivities of mosquito species towards different volatile oils has been also recorded ${ }^{3}$. Thymol, one of the major components of Lippia sidoides, was identified as an active component of the larvicidal action against Aedes aegypti causing $100 \%$ larval mortality ${ }^{16}$.

In conclusion, the essential oils of both $M$. vulgare and $T$. capitatus are biologically active agents against mosquitoes and snails, and effect showed significant time and dose dependant. Our results suggest that the essential oils of these plants may have a promising role in this regard.

\section{RESUMO}

\section{Atividades moluscicida e mosquitocida de óleos essenciais de Thymus capitatus Hoff. et Link. e de Marrubium vulgare $\mathbf{L}$.}

A destilação por arraste a vapor dos óleos essenciais de partes aéreas de Thymus capitatus Hoff. et Link. e de Marrubium vulgare L. coletadas na costa norte do Egito resultaram em rendimento de 0,5\% e $0,2 \%$, respectivamente. Resultados de análises por cromatografia gasosa acoplada à espectrometria de massas de ambas as amostras possibilitaram a identificação de $96,27 \%$ e $90,19 \%$ dos constituintes químicos respectivamente de $T$. capitatus e $M$. vulgare. Verificou-se predomínio de constituintes oxigenados $(88,22 \%$ para $T$. capitatus e $57,50 \%$ para M. vulgare, principalmente fenóis, como carvacrol $(32,98 \%)$ e timol (32,82\%) no óleo essencial de T. capitatus, e timol $(34,55 \%)$ no óleo essencial de $M$. vulgare. Avaliou-se a atividade dos óleos essenciais obtidos contra adultos e ovos de Biomphalaria alexandrina, bem como em larvas e

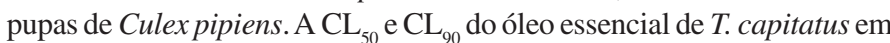
moluscos adultos foi respectivamente 200 e $400 \mathrm{ppm} / 3 \mathrm{hrs}$, enquanto para o óles essencial de $M$. vulgare verificou-se $\mathrm{CL}_{50}$ e $\mathrm{CL}_{90}$ de 50 e $100 \mathrm{ppm} / 3 \mathrm{hrs}$, respectivamente. Além disso, $M$. vulgare apresentou atividade ovicida, com CL 100 de 200 ppm/24 horas, enquanto o óleo essencial de T. capitatus não demonstrou atividade ovicida. Verificou-se ainda atividade mosquitocida, 
com $\mathrm{CL}_{50}$ e $\mathrm{CL}_{90}$ de 100 e 200 ppm/12hrs respectivamente para larvas, e 200 e 400 ppm/12hrs contra pupas de C. pipiens.

\section{REFERENCES}

1. Abdel Kader A, Hamdi SA, Rawi SM. Biological and biochemical studies on Biomphalaria alexandrina snails, treated with low concentrations of certain molluscicides (synthetic and of plant origin). J Egypt Soc Parasitol. 2005;35:841-58.

2. Adams RP. Identification of essential oil components by gas chromatography / mass spectroscopy. Illinois: Allured Publishing Corporation; 2005.

3. Amer A, Mehlhorn H. Larvicidal effects of various essential oils against Aedes, Anopheles, and Culex larvae (Diptera, Culicidae). Parasitol Res. 2006;99:466-72.

4. Al-Zanbagi NA, Barrett J, Banaja AA. Laboratory evaluation of the molluscicidal properties of some Saudi Arabian euphorbiales against Biomphalaria pfeifferi. Acta Trop. 2001;78:23-9.

5. Bowers WS. Biorational approaches for insect control. Korean J Appl Entomol. 1992;31:289-303.

6. Braga PC, Dal Sasso M, Culici M, Galastri L, Marceca MT, Guffanti EE. Antioxidant potential of thymol determined by chemiluminescence inhibition in human neutrophils and cell free systems. Pharmacology. 2006;76:61-8.

7. Braga PC, Dal Sasso M, Culici M, Bianchi T, Bordoni L, Marabini L. Anti-inflammatory activity of thymol: inhibitory effect on the release of human neutrophil elastase. Pharmacology. 2006;77:130-6.

8. Cetin H, Yanikoglu A, Cilek JE. Larvicidal activity of selected plant hydrodistillate extracts against the house mosquito, Culex pipens, a West Nile virus vector. Parasitol Res. 2010;108:943-8

9. Christensen NO, Frandsen F. An introduction to the taxonomy, morphology, biology and transmission ecology of species of the genus Schistosoma causing human African schistosomiasis. Denmark: Danish Bilharziasis Laboratory; 1985.

10. Corbet SA, Tiley C, Moorhouse T, Giam C, Pursglove S, Raby J, et al. Surface films as mosquito larvicides: partitioning the mode of action. Entomol Exp Appl. 2000;94:295307.

11. Cornwell PA, Barry BW. Sesquiterpene components of volatile oils as skin penetration enhancers for the hydrophilic permeant 5-fluorouracil. J Pharm Pharmacol. 1994;46:261-9.

12. Davis A. Schistosomiasis. In: Cook GC. Manson's Tropical Diseases. $20^{\text {th }}$ ed. London: WB Saunders; 1996. p. 1413-56.

13. Egyptian Pharmacopeia. General Organization for Governmental Printing office. Cairo: Egyptian Government; 2005. Available from: http://www.egypt.gov.eg/arabic/default. asp

14. El-Din AT. Molluscicidal effect of three monoterpenes oils on schistosomiasis and fascioliasis vector snails in Egypt. J Egypt Soc Parasitol. 2006;36:599-612.

15. Finney DJ. Probit analysis. $3^{\text {rd }}$ ed. Cambridge: Cambridge University Press; 1971.

16. Govindarajan M, Sivakumar R, Rajeswari M, Yogalakshmi K. Chemical composition and larvicidal activity of essential oil from Mentha spicata (Linn) against three mosquito species. Parasitol Res. 2012;110:2023-32.

17. Jennings W, Shibamoto T. Qualitative analysis of flavor and fragrances volatiles by glass capillary gas chromatography. $2^{\text {nd }}$ ed. New York: Academic Press; 1980.

18. Khanuja SPS, Srivastava S, Shasney AK, Darokar MP, Kumar TRS, Agarwal KK, et al. Inventors. Formulation comprising thymol useful in the treatment of drug resistant bacterial infections. United States Patent 6,824,795. 2004 Nov 30.
19. King $\mathrm{CH}$, Dangerfield-Cha $\mathrm{M}$. The unacknowledged impact of chronic schistosomiasis. Chronic Illn. 2008;4:65-79.

20. Kovendan K, Murugan K, Panneerselvam C, Mahesh Kumar P, Amerasan D, Subramaniam $\mathrm{J}$, et al. Laboratory and field evaluation of medicinal plant extracts against filarial vector, Culex quinquefasciatus Say (Diptera: Culicidae). Parasitol Res. 2012;110:10515 .

21. Lahlou M. Study of the molluscicidal activity of some phenolic compounds: structureactivity relationship. Pharm Biol. 2004;42:258-61.

22. Lemos TLJ, Monte FJQ, Matos FJA, Barbosa RCB, Lima EO. Chemical composition and antimicrobial activity of essential oils from Brazilian plants. Fitoterapia, 1992;63:2668.

23. Mansour SA, Messeha SS, El-Gengaihi SE. Botanical biocides. 4. Mosquitocidal activity of certain Thymus capitatus constituents. J Nat Toxins. 2000;9:49-62.

24. Mansour SA, El-Sharkawy AZ, Ali AR. Botanical biocides.12.Mosquitocidal activity of citrus peel oils with respect to their limonene content. Egypt J Nat Toxins. 2004;1:111-

25. Mathew N, Misra-Bhattacharya S, Perumal V, Muthuswamy K. Antifilarial lead molecules isolated from Trachyspermum ammi. Molecules. 2008;13:2156-68.

26. Muñoz-Martinez F, Lu P, Cortés-Selva F, Pérez-Victoria JM, Jiménez IA, Ravelo AG, et al. Celastraceae sesquiterpenes as a new class of modulators that bind specifically to human P-glycoprotein and reverse cellular multidrug resistance. Cancer Res. 2004;64:7130-8

27. Oparaocha ET, Iwu I, Ahanakuc JE. Preliminary study on mosquito repellent and mosquitocidal activities of Ocimum gratissimum (L.) grown in eastern Nigeria. J Vector Borne Dis. 2010;47:45-50.

28. Ottesen EA, Duke BO, Karam M, Behbehani K. Strategies and tools for the control/ elimination of lymphatic filariasis. Bull World Health Organ. 1997;75:491-503.

29. Ranson H, Rossiter L, Ortelli F, Jensen B, Wang X, Roth CW, et al. Identification of a novel class oil of insect glutathione S-transferases involved in resistance to DDT in the malaria vector Anopheles gambiae. Biochem J. 2001;359(pt 2):295-304

30. Raymond M. Présentation d'un programme d'analyse log-probit pour micro-ordinnateur. Cah ORSTOM Sér Ent Méd Parasitol. 1985;23:117-21.

31. Singh B, Patial J, Sharma P, Chandra S, Kaul P, Maity S. Role of acidity for the production of carvacrol from carvone over sulfated zircona. Indian J Chem Technol. 2011;18:21-8.

32. Tasdemir D, Kaiser M, Demirci F, Baser KHC. Essential oil of Turkish Origanum onites L. and its main components, carvacrol and thymol show potent antiprotozoal activity without cytotoxicity. Planta Med. 2006;72:1006.

33. Taubes GA. Mosquito bites back. New York Times Magazine. 1997;August 24:40-6.

34. Williams AC, Barry BW. Terpenes and the lipid-protein-partitioning theory of skin penetration enhancement. Pharm Res. 1991;8:17-24.

35. World Health Organization. Expert Committee on Bilharziasis. Molluscicides. Second Report. Geneva: WHO; 1961. (Technical Report Series No. 214).

36. World Health Organization. Molluscicide screening and evaluation. Bull World Health Organ. 1965;33:567-81

37. World Health Organization. Guidelines for determining the susceptibility or resistance of mosquito larvae to insecticides. 1981. Available from: http://www.who.int/who mimieograph/VBC/81807.

38. World Health Organization. The control of schistosomiasis. Geneva: WHO; 1985 (Technical Report No. 728). 
SALAMA, M.M.; TAHER, E.E. \& EL-BAHY, M.M. - Molluscicidal and mosquitocidal activities of the essential oils of Thymus capitatus Hoff. et Link. and Marrubium vulgare L. Rev. Inst. Med. Trop. Sao Paulo, 54(5): 281-6, 2012.

39. Yadav RP, Singh A. Efficacy of Euphorbia hirta latex as plant derived molluscicides against freshwater snails. Rev Inst Med Trop Sao Paulo. 2011;53:101-6.

40. Youssif, RS, Shaalan EA. Mosquitocidal activity of some volatile oils against Aedes caspius mosquitoes. J Vector Borne Dis. 2011;48:113-5.
41. Zarai Z, Kadri A, Ben Chobba I, Ben Mansour R, Bekir A, Mejdoub H, et al. The in-vitro evaluation of antibacterial, antifungal and cytotoxic properties of Marrubium vulgare L. essential oil grown in Tunisia. Lipids Health Dis. 2011;10:161

Received: 23 December 2011

Accepted: 3 May 2012 